\title{
Cytotoxicity and mutagenicity of cola and grape flavored soft drinks in bone marrow cells of rodents
}

\author{
Citotoxicidade e mutagenicidade de refrigerantes sabor cola e uva, em células de medula óssea de roedor
}

\author{
Elisângela DÜSMAN ${ }^{1 *}$, Alessandra Paim BERTI ${ }^{1}$, Lilian Capelari SOARES ${ }^{1}$, Veronica Elisa Pimenta VICENTINI
}

\begin{abstract}
Due to the large consumption of soft drinks in Brazil and worldwide in recent years and considering that some of the components present in their composition pose potential risks to human health, the aim of this study was to evaluate the cytotoxic and mutagenic potential of specific cola and grape-flavored soft drink brands. Bone marrow cells of Wistar rats were initially treated by gavage with one single dose of Cola or Grape soft drink, which was next offered ad libitum (instead of water) for 24 hours. A negative control treatment was performed by administering one single dose of water and a positive control administering cyclophosphamide intraperitoneally. Statistical analysis showed that the Cola and Grape soft drinks studied were not cytotoxic. However, the Cola soft drink proved mutagenic in this experiment treatment time. Therefore, this study serves as a warning about the consumption of Cola-flavored soft drink and for the need for further subchronic and chronic studies on soft drinks in order to evaluate the long term mutagenic and cytotoxic effects of these substances.
\end{abstract}

Keywords: chromosomal aberration; soft drinks; Wistar rats.

\section{Resumo}

Devido ao grande consumo de refrigerantes no Brasil e no mundo nos últimos anos, e tendo em vista que alguns dos componentes presentes na composição destes possuem potenciais danosos para os organismos, em especial o humano, o objetivo deste trabalho foi avaliar o potencial citotóxico e mutagênico de uma marca de refrigerante sabor Cola e uma de sabor Uva. Foram utilizadas como sistema-teste as células de medula óssea de ratos Wistar, tratados via gavagem com dose única do refrigerante sabor Cola ou Uva e, em seguida, fornecidos ad libitum (no lugar da água), por 24 horas. Foi feito um controle negativo, administrando água, em dose única, e um controle positivo administrando ciclofosfamida, via intraperitoneal. A análise estatística mostrou que os refrigerantes sabor Cola e Uva não foram citotóxicos. Entretanto, o refrigerante sabor Cola foi mutagênico neste sistema-teste e tempo de tratamento. Desta forma, este estudo serve de alerta para o consumo de refrigerantes sabor Cola e indica que estudos subcrônicos e crônicos com os refrigerantes devem ser realizados, a fim avaliar os efeitos mutagênicos e citotóxicos dessas substâncias a longo prazo.

Palavras-chave: aberração cromossômica; refrigerantes; ratos Wistar.

\section{Introduction}

Due to the development of modern techniques, which aim to increase the production, preservation, and packaging and improve certain properties, such as color and taste of foods, some substances in certain foods can induce mutations in the genetic material and may favor the development of tumors (HERCEG, 2007).

The consumption of foods high in sugars and other harmful substances that cause serious adverse effects when consumed inappropriately is of great concern (LUDWIG; PETERSON; GORTMAKER, 2001). Studies have linked the consumption of sugar and sweetened soft drinks with the occurrence of nontransmissible chronic diseases such as obesity, diabetes, cancer, arthritis, dyslipidemia, and atherosclerosis (BERKEY et al., 2004; JAMES; KERR, 2005; CHOI; CURHAN, 2008). Soft drinks are industrialized, non-alcoholic, carbonated beverages, with added flavors and high refreshing power. Their consumption has greatly increased in Brazil and around the world in recent years (LIMA; AFONSO, 2009; KORAB; PIETKA, 2012).
Cola-flavored are the most widely recognized and consumed soft drinks globally (RAYES, 2008). Researches have shown that soft drink consumption, in particular Cola flavored soft drinks, can cause dental erosion and reduce hardness of tooth enamel (JENSDOTTIRA; BARDOWA; HOLBROOK, 2005; WONGKHANTEE et al., 2006; CHOI et al., 2012).

The most common soft drink ingredients are water, sugar, fruit concentrate, acidulants, antioxidants, preservatives, sweeteners, and carbon dioxide. Water accounts for $88 \%$ and sugar $11 \%$ of the final product. The fruit concentrate imparts the characteristic flavor of the beverage and are composed of extracts, essential oils, and fruit and vegetable distillates. Acidulants such as citric acid, phosphoric acid, and tartaric acid regulate the sweetness of sugar, enhance flavor, and reduce the $\mathrm{pH}$ of the beverage. Antioxidants such as ascorbic acid and isoascorbic prevent the adverse influence of oxygen in the beverage, and preservatives such as sodium benzoate and potassium sorbate inhibit the growth of microorganisms.

Received 30/8/2012

Accepted 7/11/2012 (005872)

${ }^{1}$ Departamento de Biotecnologia, Genética e Biologia Celular, Universidade Estadual de Maringá - UEM, Av. Colombo, 5790, Bloco H67(11), Jardim Universitário, CEP 87020-900, Maringá, PR, Brasil, e-mail: lisdusman@hotmail.com

${ }^{*}$ Corresponding author 
The sweeteners used in diet soft drinks, such as saccharin, sodium cyclamate, aspartame, and acesulfame-K give them a sweet flavor replacing sucrose, and carbon dioxide enhances these beverages taste and appearance (PALHA, 2005; LIMA; AFONSO, 2009).

However, is worth mentioning that some of the components present in soft drinks are potentially harmful to the human body as a whole, in particular to the genetic material (ANTUNES; ARAÚJO, 2000; CHOUDHURY; PALO, 2004; KEAST; RIDDELL, 2007; RAYES, 2008; COLUCCI et al., 2011). Thus, considering that few studies have been conducted to evaluate the cytotoxic and mutagenic potential of soft drinks, the aim of this study was to investigate this potential of specific cola and grape-flavored soft drink brands in Wistar rats.

\section{Materials and methods}

\subsection{Solution treatment and Wistar rats}

The Wistar rats, three males and three females for each control and treatment group, 35 days old weighing approximately $100 \mathrm{~g}$ of body weight (bw), were obtained from the Central Vivarium of the University of Maringá (UEM). During the experiment, the animals were kept in the biotherium of Department of Biotechnology, Genetics and Cell Biology/ UEM under controlled conditions of temperature $\pm 25^{\circ} \mathrm{C}$, humidity $\pm 50 \%$, and a 12 hours light/dark photoperiod, according to the norms established by the Ethics Committee on Experimentation with Laboratory Animals/UEM (process number: PRO 031/2007).

The Cola and Grape-flavored soft drinks were obtained from a commercial source and were kept at room temperature $\left(25^{\circ} \mathrm{C}\right)$ and initially treated by gavage with one single dose $(1 \mathrm{~mL}$ ) of Cola or Grape soft drink/100 $\mathrm{g}$ bw (considering the daily intake of $600 \mathrm{~mL}$ for humans), which was degassed by gently shaking and offered ad libitum (instead of water) for 24 hours.

The treatment included two control groups: a negative, $1 \mathrm{~mL}$ water/100 $\mathrm{g}$ bw by gavage; and a positive, cyclophosphamide $1.5 \mathrm{mg} / 1 \mathrm{~mL}$ water/100 g bw injected intraperitoneally for 24 hours.

\subsection{Chromosomal aberration test}

The chromosomal aberration test was performed with bone marrow cells of Wistar rats using the method of Ford and Hamerton (1956) with modifications. The cells were disrupted in mitotic metaphase with the intraperitoneal administration of $0.5 \mathrm{~mL} / 100 \mathrm{~g}$ bw of colchicine $(0.16 \%)$ half an hour before euthanasia. The animals were euthanazed by the intraperitoneally injection of $0.5 \mathrm{~mL}$ of $4 \%$ Thionembutal - thiopental sodium ( $1 \mathrm{~g} / 25 \mathrm{~mL}$ of distilled water).

In each slide, 100 metaphases were analyzed under light microscope per animal, totaling 600 for the control and treatment groups, and the presence of gaps, breaks, fragments, and others was investigated.

Cytotoxicity was evaluated by the parameter of mitotic index (MI), which was calculated for 5,000 cells per sex totaling
10,000 cells per group. The mitotic index was calculated as a percentage ratio of the number of dividing cells to the total number of cells in these fields. The statistical calculation was performed by the Tukey test and T-Student test $(\alpha=0.05)$.

\section{Results and discussion}

Figure 1 shows the data of mitotic index average and chromosomal alterations and the respective standard deviations of the control and treatment groups. According to the statistical analysis, there were no differences in the comparisons of mitotic indices between the groups. Therefore, Cola and Grape-flavored soft drinks showed no cytotoxic effect on the bone marrow cells of the treated Wistar rats.

Santa-Maria et al. (2002) evaluated the in vitro cytotoxic potential of stimulating substances found in soft drinks such as caffeine, guarana, taurine, and some vitamins. The results corroborate those of the present study because since no stimulating cytotoxic potential was detected.

Conversely, positive results were found by Hannah, Priya and Mammen (2010) studying cytotoxicity of Coke and Pepsi soft drinks, which exhibited the inhibitory effect of mitosis by the calculation of the mitotic index in Allium cepa roots treated for 2, 24, and 48 hours.

With regard to the percentage of chromosomal alterations (Figure 1), there were statistically significant differences between the negative control $(0.3 \%)$ and the treatment with Cola-flavored soft drink $(1.2 \%-p<0.05$ by the Tukey test and $p<0.01$ by the Student's $\mathrm{T}$ test $)$ and the positive control $(21.3 \%-\mathrm{p}<0.001$ by the Tukey test and $p<0.0001$ by the Student's T test). These data indicate that the Cola-flavored soft drink was mutagenic and increased the percentage of chromosomal alterations (break off) showing clastogenic action under the treatment conditions used.

These data corroborate the results of the study of Randerath, Putman and Randerath (1993) on the formation of covalent adducts in liver cells of mice treated for 8 weeks with soft drinks, which also showed mutagenic effect of the Cola soft drink. Moreover, the non-Cola soft drinks did not cause the

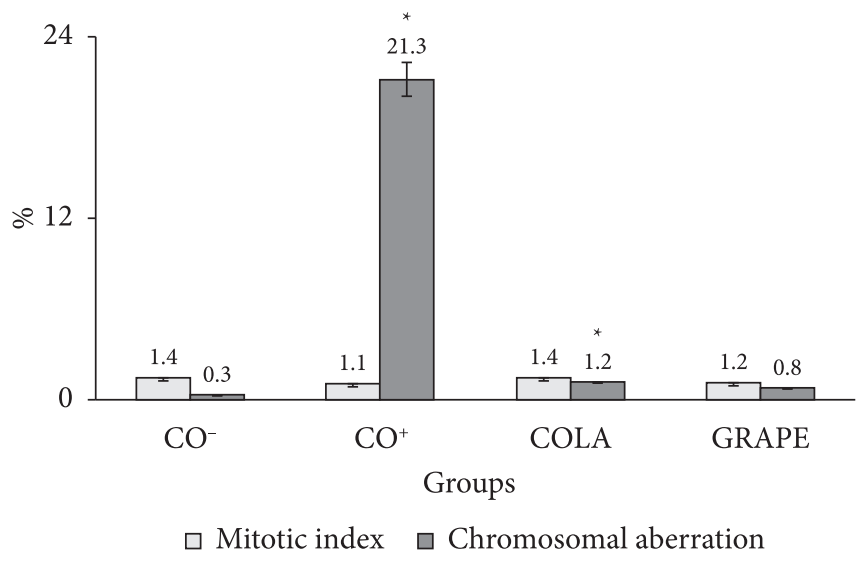

Figure 1. Mean percentage and standard deviation of mitotic index and chromosomal alterations found in the control groups treated with Cola and Grape soft drinks. ${ }^{\star}$ Statistically significant result compared to that of the negative control $\left(\mathrm{CO}^{-}\right)$. 
appearance of these adducts, similarly to the non-mutagenic activity observed for the Grape soft drink tested in this study.

Similar results were obtained by Hannah, Priya and Mammen (2010) since both Coke and Pepsi soft drinks increased the number of chromosomal aberrations in the roots of Allium cepa treated for 2, 24, and 48 hours. Rayes (2008) studied the effects of histological and microbiological samples of commercial natural and artificial orange juices and cola-flavored soft drink. The results of the Cola soft drink were alarming since it was lethal to pathogenic bacteria tested strains (Bifidobacterium bifidum and Lactobacillus acidophilus) and had deleterious effects on the normal flora of the intestinal tract and toxic effect on the mice testicular cells.

According to Rayes (2008), the damage caused by soft drinks can be attributed to their various components and acidity ( $\mathrm{pH}$ 3.5) since low $\mathrm{pH}$ can reduce the metabolic rate and the body's antioxidant defenses. Accordingly, other studies have shown that some of the ingredients of cola-flavored soft drinks tested isolatedly also showed potential harm. A test with the was performed in male Wistar rats by administering Cola nut extract daily at a concentration of $57 \mathrm{mg} / \mathrm{kg}$ for 18 weeks, and it was found that the effects of this compound were: excitement, restlessness, irritability, diuresis, hair loss, and loss of appetite and weight (IKEGWUONU; AIRE; OGWUEGBU, 1981). Furthermore, it was observed an increase in absolute weights of the liver, kidney, brain and testis and a decrease in total protein, RNA levels, and enzymatic activity of these organs.

Another ingredient present in cola soft drinks that can induce mutagenic activity is caffeine. Different concentrations of caffeine induced an increase in the percentage of micronuclei and aberrant metaphases, and the rate of chromosomal abnormalities (NEHLIG; DEBRY, 1994; CHOUDHURY; PALO, 2004; TRUTA; ZAMFIRACHE; OLTEANU, 2011). Caffeine also caused changes the DNA repair system, which leads to diseases in various organs, especially those related to the development of cardiovascular abnormalities and pancreatic cancer (ITO et al., 2003; KEAST; RIDDELL, 2007).

As for the acidulant phosphoric acid, present in Colaflavored soft drinks, Mazariegos-Ramos et al. (1995) confirmed, in children, the relationship between the consumption of soft drinks with phosphoric acid and the risk of development of hypocalcemia, a disease that results in a low concentration of calcium in the blood, which can cause tetanus, subnormal intelligence, depression, and cardiovascular problems among others.

Caramel is the main color additive in Cola soft drinks, and it showed mutagenic activity in Salmonella typhimurium TA 100 (JENSEN; WILLUMSEN; KNUDSEN, 1983). Caramel coloring also caused convulsions when administered to rats, mice, and chickens, and it adversely affected the levels of white blood cells (lymphocytes) in laboratory animals and inhibited the absorption of vitamin B6 in rabbits due to the presence of an impurity called 4 Methylimidazol produced by processes that use ammonia (TUORMAA, 1994). A 4 Methylimidazol presented carcinogenic potential in mice treated with high concentrations of this substance (HOUBEN; PENNINKS, 1994) for 2 years and resulted in an increase in excitability and hyperactivity and the incidence of mononuclear cell leukemia, histiocytosis of the liver, chronic inflammation, adenocarcinoma, bronchial and alveolar epithelial hyperplasia (CHAN et al., 2008). Thus, since mutagenesis and carcinogenesis processes are linked together (LOUREIRO; DI MASSIO; MEDEIROS, 2002), positive results for mutagenicity of Cola-flavored soft drink alert to the presence of substances with carcinogenic potential in this kind of beverage.

In addition to the mutagenic potential of the ingredients commonly found in soft drinks, Majumdar (2010) found alarming concentrations of pesticides in samples of Pepsi and Coca-Cola soft drinks collected from markets in New Delhi and surrounding areas in India. This is dangerous because several studies have demonstrated the genotoxic and carcinogenic potential of different pesticides (CONTRERAS et al., 1998; PACHECO; HACKEL, 2002; BORTOLI; AZEVEDO; SILVA, 2009).

It is noteworthy that the mutagenic effect of Cola soft drink tested in this study, following its acute administration by gavage $(1 \mathrm{~mL})$ and then offered ad libitum for 24 hours. This indicates that the consumption of high doses of this beverage, even for a short time, produce a damaging effect to the genetic material of animals. This is a cause for concern since many people consume this type of beverage sporadically, but at higher doses, and most people consume it fairly often, on a daily basis sometimes, and according to a survey conducted by the Brazilian Institute of Geography and Statistics (IBGE) in 2008/2009 (INSTITUTO..., 2011), the average daily per capita consumption of soft drinks by Brazilians on average is of $94.7 \mathrm{~mL} /$ day.

Therefore, although the values of additives in Cola-flavored soft drinks are within the acceptable daily intake (ADI) limits allowed by ANVISA (AGÊNCIA..., 2007), a high consumption of these substances alone or in combination can result in mutagenicity, as identified in this study. On the other hand, it is probable that mutagenic potential substances in Cola soft drink were not present in the Grape soft drink, which showed no clastogenic/mutagenic effect in this study. Among the substances present in Cola-flavored soft drinks which is not present Grape soft drinks are the Cola nut extract, caffeine (until $20 \mathrm{mg} / 100 \mathrm{~mL}$ ), caramel coloring IV (200 mg/kg bw) and phosphoric acid (acidulant INS 338 - maximum allowed $0.07 \mathrm{~g} / 100 \mathrm{~mL}$ ). Instead, the following substances are present in the grape flavored soft drinks: natural Grape juice 10\%, citric acid (acidulant INS 330 - maximum allowed 0.01-0.03 mg/100 $\mathrm{mL}$ ), sodium benzoate (preservative INS 211 - maximum allowed $0.05 \mathrm{mg} / 100 \mathrm{~mL}$ ), and the colorants amaranth (INS 123 - maximum allowed $0.005 \mathrm{mg} / 100 \mathrm{~mL}$ ), brilliant blue (INS 133 - maximum allowed $0.01 \mathrm{mg} / 100 \mathrm{~mL}$ ) and tartrazine (maximum allowed $0.01 \mathrm{mg} / 100 \mathrm{~mL}$ ). Carbonated water, sugar, and artificial flavor are present in these two soft drinks.

With respect to the color additive present in the Grapeflavored soft drink, several results obtained corroborate the mutagenicity negative results. Poul et al. (2009) showed that the acute exposure oral to food dye additives amaranth and tartrazine, present in this soft drink, did not induce genotoxic effects in the intestine of mice as in the micronucleus test. AlMossawi (1983) showed that amaranth should be considered 
a weak mutagen. Clode et al. (1987) showed that at doses up to $1250 \mathrm{mg} / \mathrm{kg} / \mathrm{day}$ in rats, this colorant showed no adverse effects on fertility, hematological parameters, and serum chemistry or tumor incidence. Borzelleca and Hallagan (1988) also showed that tartrazine was not toxic or carcinogenic in a chronic study on rats. Furthermore, the dye Brilliant Blue FCF, another constituent of the Grape-flavored soft drinks, did not present mutagenic in the Ames test (OZAKI et al., 1998) and was not toxic or carcinogenic in rats and mice (BORZELLECA; HOGAN, 1985; BORZELLECA; DEPUKAT; HALLAGAN, 1990).

The study conducted by Akintonwa et al. (2007) also showed that conservative sodium benzoate, found in Grape soft drinks, showed no mutagenic activity in the Ames test in Escherichia coli. Even at low concentrations, this substance was not genotoxic to cells in human peripheral lymphocytes in vitro (MPOUNTOUKAS et al., 2008). And the negative results for mutagenicity of citric acid, acidulant present in Grape-flavored soft drinks, to Salmonella typhimurium using the Ames test also corroborate the data of this study (AL-ANI; AL-LAMI, 1988).

However, worrying results were obtained by Lino and Pena (2010), who found levels greater than the maximum levels permitted by Laws of benzoic acid, sorbic acid, saccharin, conservatives, and sweeteners in several samples of soft drinks evaluated in Portugal, a fact that indicates potential harm to consumers of soft drinks, and thus suggests routine studies on cytotoxic and mutagenic effects of these drinks.

With regard to the types of chromosome alterations found in the treatments with Cola and Grape soft drinks, it is observed that the they were predominantly chromatid breaks, $100 \%$ (5 alterations) in the Grape soft drink and 85\% (6 alterations) in the Cola soft drink. Natarajan (2002) reported that some chemical agents, like those case of soft drinks do not cause many double-stranded DNA breaks, but rather other lesions, such as chromatid-type aberrations. Accordingly, only one (15\%) chromosome break type change was found in the treatment with the Cola-flavored soft drink.

\section{Conclusion}

This study serves as a warning about the consumption of Cola-flavored soft drink, which showed mutagenic potential in the bone marrow of Wistar rats treated in vivo. However, further subchronic and chronic studies on both soft drinks tested to evaluate the cytotoxic and mutagenic long term effects of these substances are recommended since some soft drinks are consumed daily by a significant proportion of the world population.

\section{Acknowledgements}

The authors are grateful to the Laboratory of Cytogenetics and Mutagenesis staff of the State University of Maringá - UEM.

\section{References}

AKINTONWA, A. et al. The mutagenic potentials of potassium bromate and some commonly used food additives. African Journal of Biotechnology, v. 6, n. 8, p. 1004-1006, 2007.
AL-ANI, F. Y.; AL-LAMI, S. K. Absence of mutagenic activity of acidity regulators in the Ames Salmonella/microsome test. Mutation Research, v. 206, n. 4, p. 467-470, 1988. http://dx.doi. org/10.1016/0165-1218(88)90055-9

AL-MOSSAWI, M. A. J. The mutagenic effect of amaranth (FD and C red no. 2) in bacteria and yeast. Environment International, v. 9 , n. 2 , p. $145-148,1983$. http://dx.doi.org/10.1016/01604120(83)90067-3

ANTUNES, L. M. G.; ARAÚJO, M. C. P. Mutagenicidade e Antimutagenicidade dos principais corantes para alimentos. Revista de Nutrição, v. 13, n. 2, p. 81-88, 2000.

AGÊNCIA NACIONAL DE VIGILÂNCIA SANITÁRIA - ANVISA. Resolução da Diretoria Colegiada - RDC no 5 , de 15 de janeiro de 2007. Atribuição de Aditivos e seus Limites Máximos para a Categoria de Alimentos 16.2: Bebidas Não Alcoólicas, Subcategoria 16.2.2: Bebidas Não Alcoólicas Gaseificadas e Não Gaseificadas. Diário Oficial da República Federativa do Brasil, Brasília, DF, 17 jan. 2007. n. 182, p. 56.

BERKEY, C. S. et al. Sugar-added beverages and adolescent weight change. Obesity Research, v. 12, n. 5, p. 778-88, 2004. PMid:15166298. http://dx.doi.org/10.1038/oby.2004.94

BORTOLI, G. M.; AZEVEDO, M. B.; SILVA, L. B. Cytogenetic biomonitoring of Brazilian workers exposed to pesticides: Micronucleus analysis in buccal epithelial cells of soybean growers. Mutation Research, v. 675, p. 1-4, 2009. PMid:19386239. http:// dx.doi.org/10.1016/j.mrgentox.2009.01.001

BORZELLECA, J. F.; DEPUKAT, K.; HALLAGAN, J. B. Lifetime toxicity/carcinogenicity studies of FD \& C blue No. 1 (Brilliant blue FCF) in rats and mice. Food and Chemical Toxicology, v. 28, n. 4, p. 221-234, 1990. http://dx.doi.org/10.1016/0278-6915(90)90034-K

BORZELLECA, J. F.; HALLAGAN, J. B. Chronic toxicicity/ carcinogenicity studies of FD \& C Yellow No. 5 (Tartrazine) in rats. Food and Chemical Toxicology, v. 26, n. 3, p. 179-187, 1988. http:// dx.doi.org/10.1016/0278-6915(88)90117-2

BORZELLECA, J. F.; HOGAN, G. K. Chronic toxicity/carcinogenicity study of FD \& C blue no. 2 in mice. Food and Chemical Toxicology, v. 23 , n. 8 , p. 719-722, 1985. http://dx.doi.org/10.1016/02786915(85)90264-9

CHAN, P. C. et al. Toxicity and carcinogenicity studies of 4-methylimidazole in F344/N rats and B6C3F1 mice. Archives of Toxicology, v. 82, n. 1, p. 45-53, 2008.

CHOI, H. K.; CURHAN, G. Soft drinks, fructose consumption, and the risk of gout in men: prospective cohort study. British Medical Association, v. 336, n. 7639, p. 309-312, 2008.

CHOI, S. et al. Potential effects of tooth-brushing on human dentin wear following exposure to acidic soft drinks. Journal of Microscopy, v. 247, n. 2, p. 176-185, 2012. PMid:22670800. http:// dx.doi.org/10.1111/j.1365-2818.2012.03630.x

CHOUDHURY, R. C.; PALO, A. K. Modulatory effects of caffeine on methotrexate-induced cytogenotoxicity in mouse bone marrow. Environmental Toxicology and Pharmacology, v. 15, p. 79-85, 2004. PMid:21782683. http://dx.doi.org/10.1016/j. etap.2003.10.001

CLODE, S. A. et al. Long-term toxicity study of amaranth in rats using animals exposed in utero. Food and Chemical Toxicology, v. 25, n. 12, p. 937-946, 1987.

COLUCCI, A. C. A. et al. Relação entre o consumo de açúcares de adição e a adequação da dieta de adolescentes residentes no município de São Paulo. Revista de Nutrição, v. 24, n. 2, p. 219-231, 2011. 
CONTRERAS, O. P. et al. Organochlorine exposure and breast cancer risk in Colombian women. Cadernos de Saúde Pública, v. 14, n. 3, p. 125-132, 1998.

FORD, C. E.; HAMERTON, J. L. A colchicine, hypotonic citrate, squash sequence for mammalian chromosome. Stain Technology, v. 31, p. 247-251, 1956. PMid:13380616.

HANNAH, C.; PRIYA, E. J. S.; MAMMEN, A. Duration dependent mutagenic study of Cola drinks on Allium cepa L. Biosciences Biotechnology Research Asia, v. 7, n. 2, p. 807-812, 2010.

HERCEG, Z. Epigenetics and cancer: towards an evaluation of the impact of environmental and dietary factors. Mutagenesis, v. 22, n. 2, p. 91-103, 2007. PMid:17284773. http://dx.doi.org/10.1093/ mutage/gel068

HOUBEN, G. F.; PENNINKS, A. H. Immunotoxicity of the color additive Caramel Color III: a review on complicated issues in the safety evaluation of a food additives. Toxicology, v. 91, p. 289-301, 1994. http://dx.doi.org/10.1016/0300-483X(94)90016-7

INSTITUTO BRASILEIRO DE GEOGRAFIA E ESTATÍSTICA - IBGE. Pesquisa de Orçamentos Familiares 2008-2009: Análise do Consumo Alimentar Pessoal no Brasil. Rio de Janeiro: Coordenação de Trabalho e Rendimento, IBGE, 2011. 150 p.

IKEGWUONU, F. I.; AIRE, T. A.; OGWUEGBU, S. O. Effects of kolanut extract administration on the liver, kidney, brain, testis and some serum constituents of the rat. Journal of Applied Toxicology, v. 1, p. 292-294, 1981. PMid:6193164. http://dx.doi.org/10.1002/ jat. 2550010603

ITO, K. et al. Caffeine induces G2/M arrest and apoptosis via novel p53 dependent pathway in NB4 promyelocytic leukemia cells. Journal of Cellular Physiology, v. 196, p. 276-283, 2003. PMid:12811820. http://dx.doi.org/10.1002/jcp.10289

JAMES, J.; KERR, D. Prevention of childhood obesity by reducing soft drinks. International Journal of Obesity, v. 29, p. S54-S57, 2005. http://dx.doi.org/10.1038/sj.ijo.0803062

JENSDOTTIRA, T.; BARDOWA, A.; HOLBROOK, P. Properties and modification of soft drinks in relation to their erosive potential in vitro. Journal of Dentistry, v. 33, p. 569-575, 2005. PMid:16005796. http://dx.doi.org/10.1016/j.jdent.2004.12.002

JENSEN, N. J.; WILLUMSEN, D.; KNUDSEN, I. Mutagenic activity at different stages of an industrial ammonia caramel process detected in Salmonella typhimurium TA 100 following pre-incubation. Food and Chemical Toxicology, v. 21, p. 527-530, 1983. http://dx.doi. org/10.1016/0278-6915(83)90135-7

KEAST, R. S. J.; RIDDELL, L. J. Caffeine as a flavor additive in softdrinks. Appetite, v. 49, p. 255-259, 2007. PMid:17189661. http:// dx.doi.org/10.1016/j.appet.2006.11.003

KORAB, H. E.; PIETKA, M. J. Soft drink. Encyclopædia Britannica Inc. Disponível em: <http://www.britannica.com/EBchecked/ topic/552397/soft-drink>. Acesso em: 30 jul. 2012.

LIMA, A. C. S.; AFONSO, J. C. A Química do Refrigerante. Química Nova na Escola, v. 31, n. 3, p. 1-6, 2009.

LINO, C. M.; PENA, A. Occurrence of caffeine, saccharin, benzoic acid and sorbic acid in soft drinks and nectars in Portugal and subsequent exposure assessment. Food Chemistry, v. 121, p. 503-508, 2010. http://dx.doi.org/10.1016/j.foodchem.2009.12.073

LOUREIRO, A. P. M.; DI MASSIO, P.; MEDEIROS, M. H. G. Formação de adutos exocíclicos com bases de DNA: Implicações em mutagênese e carcinogênese. Química Nova, v. 25, n. 5, p. 777-793, 2002. http:// dx.doi.org/10.1590/S0100-40422002000500014
LUDWIG, D. S.; PETERSON, K. E.; GORTMAKER, S. L. Relation between consumption of sugar-sweetened drinks and childhood obesity: a prospective, observational analysis. Lancet, v. 357, p. 505-508, 2001. http://dx.doi.org/10.1016/S0140-6736(00)04041-1

MAJUMDAR, S. Food Hazards and Food Security. Everyman's Science, v. 44, n. 6, p. 348-355, 2010.

MAZARIEGOS-RAMOS, E. et al. Consumption of soft drinks with phosphoric acid as a risk factor for the development of hypocalcemia in children: A case-control study. The Journal of Pediatrics, v. 126, n. 6 , p. $940-942,1995$. http://dx.doi.org/10.1016/S00223476(95)70215-6

MPOUNTOUKAS, P. et al. Cytogenetic study in cultured human lymphocytes treated with three commonly used preservatives. Food and Chemical Toxicology, v. 46, n. 7, p. 2390-2393, 2008.

NATARAJAN, A. T. Chromosome aberrations: past, present and future. Mutation Research, v. 504, p. 3-16, 2002. http://dx.doi.org/10.1016/ S0027-5107(02)00075-1

NEHLIG, A.; DEBRY, G. Potencial genotoxic, mutagenic and antimutagenic effects of coffee: A review. Mutation Research, v. 317 , n. 2 , p. $145-162$, 1994. http://dx.doi.org/10.1016/01651110(94)90022-1

OZAKI, A. et al. Mutagenicity and DNA-damaging Activity of Decomposed Products of Food Colours under UV Irradiation. Food and Chemical Toxicology, v. 36, p. 811-817, 1998. http:// dx.doi.org/10.1016/S0278-6915(98)00039-8

PACHECO, A. O.; HACKEL, C. Instabilidade cromossômica induzida por agroquímicos em trabalhadores rurais na região de Passo Fundo, Rio Grande do Sul, Brasil. Cadernos de Saúde Pública, v. 18 , n. 6 , p. $1675-83,2002$. http://dx.doi.org/10.1590/S0102$311 \mathrm{X} 2002000600022$

PALHA, P. G. Tecnologia de refrigerantes. Rio de Janeiro: AmBev, 2005.

POUL, M. et al. Lack of genotoxic effect of food dyes amaranth, sunset yellow and tartrazine and their metabolites in the gut micronucleus assay in mice. Food and Chemical Toxicology, v. 47, n. 2, p. 443-448, 2009. PMid:19095036. http://dx.doi.org/10.1016/j. fct.2008.11.034

RANDERATH, K.; PUTMAN, K. L.; RANDERATH, E. Flavor constituents in cola drinks induce hepatic DNA adducts in adult and fetal mice. Biochemical and Biophysical Research Communications, v. 192, n. 1, p. 61-68, 1993. PMid:8476434. http:// dx.doi.org/10.1006/bbrc.1993.1381

RAYES, A. A. H. Effect of Some Drinks on the Benificial Probiotic Bacteria and the Structure of Testis of Male Albino Mice. Journal of Applied Sciences Research, v. 4, n. 7, p. 803-813, 2008.

SANTA-MARIA, A. et al. In Vitro Toxicity of Stimulant Soft Drinks. Ecotoxicology and Environmental Safety, v. 53, p. 70-72, 2002. PMid:12481860. http://dx.doi.org/10.1006/eesa.2001.2213

TRUTA, E.; ZAMFIRACHE, M. M.; OLTEANU, Z. Caffeine induced genotoxic effects in Phaseolus vulgaris $\mathrm{L}$. and Raphanus sativus $\mathrm{L}$. Botanica Serbica, v. 35, n. 1, p. 49-54, 2011.

TUORMAA, T. U. The Adverse Effects of Food Additives on Health: A Review of the Literature with Special Emphasis on Childhood Hyperactivity. Journal of Orthomolecular Medicine, v. 9, n. 4, p. 225-243, 1994.

WONGKHANTEE, S. et al. Effect of acidic food and drinks on surface hardness of enamel, dentine, and tooth-coloured filling materials. Journal of Dentistry, v. 34, p. 214-220, 2006. PMid:16087287. http:// dx.doi.org/10.1016/j.jdent.2005.06.003 